\title{
The Evaluation of Schools Accreditation Program in Palembang City South Sumatera 2018
}

\author{
Dewi Astenia ${ }^{1}$, Rugaiyah ${ }^{2}$, Neti Karnati ${ }^{3}$ \\ \{dewiastenia@yahoo.co.id ${ }^{1}$, rugaiyah@unj.ac.id ${ }^{2}$, neti.karnati@unj.ac.id ${ }^{3}$ \} \\ Universitas Negeri Jakarta, Indonesia ${ }^{123}$
}

\begin{abstract}
This study aims at evaluating accredited programs in senior high schools located in Palembang city. The study makes use of a qualitative research approach through evaluation techniques. The research models used are; implementation of Public Policy Communications, Resources, Dispositions Bureaucratic Structure. The data collection techniques adopted in order to obtain the required information are documentation, interviews and observation. Data gathered were examined using Miles and Huberman analysis strategy which comprises of three activities or processes that occur simultaneously namely: data reduction, display and drawing conclusion/verification. The results shows that in order to correctly implement accredited programs on BAN-S/M in the city of Palembang, 4 constutients namely Communication, Resources, Disposition, and Structural Biro carriage must be well-matched. However, the results of implementing accredited programs in the city of Palembang is yet to reach its peak, as the required standards is yet to meet the evaluation criteria. Schools with the A title are still below $50 \%$ of the total number of schools; therefore, budgetary help from the regions is needed to speed up the fulfillment of eight national education standards.
\end{abstract}

Keywords: Evaluation, School Accreditation, SMA Students

\section{Introduction}

The policy of the National Education Office of the South Sumatra Province have been formed through the Regional Regulation number II of the year 2000 and amendment number 6 of 2001. The policy is tasked with carrying out the decentralization and deconcentration tasks in the national education sector, providing guidance, management, and support/assistance to all educational institutions within every path, type and level.

Results obtained from the accreditation of )Badan Akreditasi Provinsi Sekolah/Madrasah Provinsi Sumatera Selatan in 2016, shows that senior schools education units up for the city of Palembang, had as many as 93 institutions $(41.52 \%)$ ranking A, 81 institutions or $36.16 \%$ with Rank B, 44 institutions (19.64\%) ranking C and as many as 6 institutions (2.68\%) not accredited. This means that MA schools have met the national education accredition standard of $41.52 \%$, 
while the remaining percentage $(58.48 \%)$ are yet to meet the national education standards. For high schools located in SMK in Palembang city, 119 institutions ( 54.09\%) ranked A, 81 institutions (36.16\%) ranked $\mathrm{B}$, while 20 institutions (9\%) ranked $\mathrm{C}$ with zero non-accredited institution. This means that about $54.09 \%$ of all vocational schools in the city of Palembang have met the national education standards while the remaining $45.4 \%$ are yet to meet the up.

(Badan Akreditasi Provinsi Sekolah/Madrasah Provinsi Sumatera Selatan, 2016) The inconsistency that occurs with respect to the problem is the low value of $\mathrm{S} / \mathrm{M}$ accreditation. From the results obtained it can be seen that A accreditation has a value of 10\%, B $40 \%$ and C $50 \%$. Based on the results of the above description, it is necessary to study and analyze the various causes of these problems. Therefore, as a result of this, this research explores the Evaluation of the Implementation of the S/M Accreditation Program in Palembang City.

\section{Literature Review}

\subsection{Program Evaluation}

(Hamzah, 2014) argued that evaluation is a process of collecting data to determine if its goals have been achieved. In addition, Owan (Owen, 2006) states that program is a set of planned activities that functions interchangeably in order to identify specified changes in a set of audience. In other words, a program is a series of activities planned or directed to bring about the recognizable and identifiable changes in a particular set of people. (Huey Tsyh Chen, 2005)defines program evaluation as a tool for assessing approaches, techniques, and knowledge to systematically assess and enhance the planning, implementation, and effectiveness of programs.

\subsection{Accreditation}

Jeffrey W. Alstete, 2007 reveals that accreditation is a voluntary private sector that detemines what to seek. It is achieved after evaluation of all institutions and continues until officially terminated or withdrawn, though it is subject to periodic reviews and requirements, as determined by the commission. )According to Insung Jung, 2012, Accreditation is the process of assessing and reviewing an institution's various program or course of study to certify that it meets the standard educational requirements.

Figen (Karaferye, 2017) stated during the accreditation process; topics such as management, academic staff, physical environment features and facilities, library, registration procedures, students, academic calender, teaching methods, measurement-evaluation, teaching-learning tools and laboratories are subjected to a multifaceted study and evaluation. 


\section{Research Design}

This research was conducted at the South Sumatra Province School with the target on high /vocational schools in Palembang City. The study was carried out from March 2016 until October 2017. The qualitative research method was the model used. This study aims to reveal the phenomena contained in the process of implementing programs that take place in high school schools in Palembang. The design of evaluating research program implementation uses the policy model of George Edward III (George, 1980); 1. Communication 2. Resources 3. Dispositions 4. Bureaucratic Structure.

\section{Discussion}

\subsection{Accreditation Program}

James (Sanders, 2003) defined accreditation program as an educational activity conducted on an ongoing basis. Program is a collection of special activities designed in order to achieve predetermined goals. It is are carried out by providing information on the feasibility of schoolsbased on the National Education Standards, by ratinggiving , mapping based on SNPs, and giving responsibility to stakeholders as public accountability. In accordance with accreditation policies and systems. School accreditation is a series of activities carried out by the institution through a self-evaluation process and by BAN-S/M South Sumatra Province through visitation. This is done to obtain accurate, objective, fair and transparent information on each component.

\subsection{Facility and Infrastructure}

The strategy is carried out to obtain facilities and infrastructure for the implementation of accreditation of Schools in Madrasas, South Sumatra province. This is done by making proposals for infrastructure facilities to the Provincial Education Service in order to get recommendations from the Education Office and the Directorate of Vocational Education. Support for facilities and infrastructure was also carried out through collaboration with third parties (school committees), assistance from AUSAID and budgeting in the APBN. It's quite unfortunate that most schools have limited facilities and infrastructure, thereby, making the teaching and learning process quite difficult. However, institutions that wrote to the educational board, where assisted with modern library shipments, teaching tools, conducive learning environment with the elevation of new buildings, etc. 


\subsection{Human Resources}

In launching the wheels of the S/M accreditation program in South Sumatra which was formed by the BAN secretariat team, the administrative activities were regulated for smooth administrative function and professional in IT capabilities, committed with highly dedicated (Badan Akreditasi Sekolah/Madrasah Provinsi Sumatera Selatan, 2016).

The BAN-S/M Secretariat Team of South Sumatra Province was formed because of the high demands of technical guidance. Government regulations were fulfilled by certain criteria, namely dedication, and IT skills. Applicant with the right skills were set aside , trained and employed for assistance.

\subsection{BAN-S/M Coordination Meeting with UPA-S/M}

In the BAN-S/M coordination meeting with UPA-S/M, the draft accreditation program will be discussed together with relevant stakeholders in the education sector. With regards to this, it is necessary to unify the vision and mission of the Provincial Education Office, the Regional Offices of the Ministry of Religion of South Sumatra Province, LPMP, UPA-S/M, District / City Department of Religion Office, District / City Education Service, BAN-S Members / M and the secretariat in achieving accreditation programs. Determination of policies resulting from meetings about accreditation programs, is sometimes terminated by sending the wrong participants to represent the committee.

\subsection{Training on Renewal of Accreditation Assessors}

Training on renewal of accreditation assessors was conducted in order to ascertain those who are trustworthy and competent in conducting the accreditation in an objective and accountable manner. At the same time information about the latest developments in the implementation of school / madrasah education was provided to them. However, assigning those that will carry out the assignment, is often constrained by official of the principal agency, who fail to carry out their responsibilities effectively and efficiently.

\subsection{Monitoring and Evaluation}


Controlling is the process of monitoring, comparing and correcting work performance (Mukhtar, 2013). However, sometimes the officers sent to evaluate and examine schools for proper accreditation fail to perform their duties optimally. This affects the results obtained and the school/s in question will not achieve the right accreditation values .

Some of the obstacles associated with the implementation of accreditation monitoring and evaluation, include geographical location which varies from one region to another. The location of a very far-flung area between one village and another village will make it difficult for accreditors to visit using private or public transportation system.

\subsection{Achievement of S / M accreditation performance results}

From the results of observations in the field, organizing accreditation for the implementation of programs in the city of Palembang is yet to achieve maximum category. The achievement associated with the accreditation standards has failed to meet the established evaluation criteria, with most schools having A title below $50 \%$ of the total number of schools. The data obtained from the South Sumatra School / Madrasah School Accreditation Agency (Badan Akreditasi Sekolah/Madrasah Provinsi Sumatera Selatan, 2016) states that the results of the school accreditation from 2008 to 2016 for Palembang City are detailed as follows; a.SMA / SMK / MA for A accreditation status; 96/25\%, b.SMA / SMK / MA for B accreditation status; 67 / 17.3\%, c.SMA / SMK / MA for accreditation status C; 17 / 4.4\%. For accreditation A and B all 8 standard values are spread almost the same and the lowest standard $\mathrm{C}$ is located in the standard values of teaching staff and education, facilities and infrastructure, graduation competence and funding.

For that, budget assistance from the regions is needed to accelerate the fulfillment of eight national education standards. The experience of school accreditation has been due to several obstacles and constraints, among others; a. The limited number and incentives for assessors in conducting visits to schools, b lack of government support for school accreditation, especially in the Implementation Unit, c. the management system and education supervisors in the regions are still weak,d. geographically located where schools are in remote areas so that communication and transportation are difficult and require large costs, e. Limited number of professional and trusted assessors. H. Budiono as Secretary of the Education Office of the Province of South Sumatra (Badan Akreditasi Sekolah/Madrasah Provinsi Sumatera Selatan, 2016) stated the comprehensive principle in accreditation is that improving the ranking of schools can only be realized through overall quality improvement including eight national standards of education.. 


\section{Conclusion}

Based on the results of the research and discussions above, it can be concluded that the evaluation of the implementation of the accredited program in BAN-S / M located in the city of Palembang comprises of 4 components namely; Communication, Resources, Disposition, and Structural Biro carriage that has been well-matched. However, the results in the city of Palembang is yet to achieve maximum category. Accreditation standards still does not meet the established evaluation criteria, schools which have the A title are still below $50 \%$ of the total number of schools. Therefore budgetary assistance from the regions is needed to accelerate the fulfillment of eight national education standards.

\section{References}

[1] Ali Hamzah,Evaluasi Pembelajaran Matematika, (Jakarta: PT Raja Grafindo Persada, 2014), h.13.

[2] John M Owen.: Program Evaluation: Form and Approaches, (Singapore: Allen \& Unwin, 2006), h.26.

[3] Huey Tsyh Chen.: Practical Program Evaluation: Assesing and Improving Planning,

[4] George III Edward : implementing public policy, 1980.

[5] James R Sanders.: Chair The Program Evaluation Standards How to Assess Evaluations of Educational Programs, (USA : Sage Publications Ltd,1994), h.3.

[6] Jeffrey W. Alstete.: College Accreditation: Managing Internal Revitalization and Public Respect, (New York: Palgrave Macmillan Ltd,2007), h 18.

[7] Insung Jung.: Quality Assurance and Accreditation in Distance Education and e-Learning

[8] Models,Policies and Research, (New York: Routledge, 2012 ), h 3.

[9] Figen Karaferye.: An Introduction to Program Accreditation in Foreign Language School in Turkey. European Journal of Multidisciplinary Studies. Vol 2 (2). P. 62-66.2017.

[10] Badan Akreditasi Provinsi Sekolah/ Madrasah Provinsi Sumatera Selatan. Hasil Pelaksaan Akreditasi Satuan Pendidikan SMA/ MA Per kabupaten/ Kota Provinsi Sumatera Selatan sampai dengan Tahun 2016 berdasarkan peringkat akreditasi 